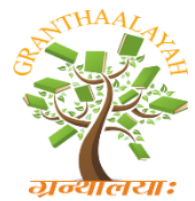

$$
\begin{aligned}
& \text { INTERNATIONAL JOURNAL OF RE } \\
& \text { GRANTHAALAYAH } \\
& \text { A knowledge Repository }
\end{aligned}
$$

Science

\title{
ANTIBIOTIC USE IN SLOVENIAN HOSPITALS
}

\author{
Tatjana Pokrajac *1, Milan Čižman ${ }^{2}$, Bojana Beovič ${ }^{2}$ \\ ${ }^{*}$ Chair of public health, Medical Faculty, University Ljubljana, Slovenia \\ ${ }^{2}$ Clinic for infectious diseases and febrile state, University Clinical Centre Ljubljana, Slovenia
}

\begin{abstract}
Abstract: Motivation/Background: Antibiotics are commonly overused and misused what increase the emergence of resistant organisms, side- effects and costs. To assess the appropriate use of antibiotics many methods are available. The aim of the present study is to find correlation between antibiotic use and case mix index (CMI) in Slovenian hospitals.

Method: In retrospective study (in the years between 2004 and 2013) we correlated the total consumption of antibiotics for systemic use and CMI. Weighted linear regression test analysis was performed to determine correlation between defined daily dose (DDD) / 100 admissions and DDD / 100 bed-days and CMI.

Results: The total antibiotic consumption in all included hospitals was in mean 317.69 DDD / 100 admissions and 58.88 DDD / 100 bed days, respectively. CMI range were from 1.25 to 3.55. A significant correlation between consumption expressed in DDD / 100 admissions and CMI $(\mathrm{p}=$ 0.028) and DDD / 100 bed days and CMI ( $\mathrm{p}=0.008$ ) was found. Conclusions: Thus, detailed analysis of correlations between DDD of antibiotics and CMI may constitutes a proper use of antibiotics.
\end{abstract}

Keywords: Antibiotics; Case Mix Index; Defined Daily Dose; General Hospitals; University Medical Centres.

Cite This Article: Tatjana Pokrajac, Milan Čižman, and Bojana Beovič. (2019). "ANTIBIOTIC USE IN SLOVENIAN HOSPITALS." International Journal of Research - Granthaalayah, 7(11), 249-258. https://doi.org/10.29121/granthaalayah.v7.i11.2020.364.

\section{Introduction}

Antibiotics are commonly used in hospitalized patients (range 19-59\%) (1). Large variations in total and pattern of use have been found between countries and between hospitals in the country $(2,3)$. The most common infection types are respiratory tract $(24 \%)$, skin bone, and joint (18\%), intra-abdominal organs $(16 \%)$, urinary tract $(11 \%)(1,4-6)$. Antibiotics are commonly overused and misused what increase the emergence of resistant organisms, side- effects and costs. To assess the appropriate use of antibiotics many methods are available. The most accurate is patient-level surveillance what is time consuming and limited to a small number of patients (7). Point prevalence study survey is useful tool to judge the appropriateness of antibiotic use (8). The case mix index 
(CMI) is an economic surrogate marker (i.e. the total cost weights of all inpatients per a defined time period divided by the number of admissions) to describe the average patients' morbidity of individual hospitals (9). In the first study in 2008, Kuster et al. proved methodology and strong significant correlation between defined daily dose (DDD) of antibiotics / 100 admissions and DDD / 100 bed-days and CMI in Canton Zurich, Switzerland hospitals (9). Our study is the first such survey in Slovenia. The aim of the present study is to find correlation between antibiotic use and CMI in 12 Slovenian hospitals including two University hospitals and ten general hospitals.

\section{Participants and Methods}

\subsection{Participants}

We performed a retrospective observational study of antibiotic use and CMI in two University Medical Centres, Ljubljana and Maribor and another 10 acute care hospitals, a state in Slovenia, during the study period between 2004 to 2013.

The study included all patients hospitalized in 12 Slovenian hospitals from 2003 to 2014 illnesses by infectious diseases. Patients have been registered in the national statistical collections, which will be presented below, patient information is anonymous.

\subsection{Methods}

Number of admissions and number of bed-days of infectious diseases were calculated from electronic health information system of hospital care (ZISBO) of the National Institute of Public Health (NIPH) (13) of each patient hospitalized for $\geq 24$ hours in the same hospital unit counting the days of admission and discharge together as one bed-day. For the all studied hospitals, aggregate hospital antibiotic consumption data defined daily dose (DDD) were collected from the hospital pharmacies and entered into a Microsoft Office Excel 2010 database. The 2014 version (group J01 (Antibacterial for system use*)) of the ATC Index with DDDs was used. DDD per 100 admissions and DDD per 100 bed-days were calculated for each hospital. CMIs for patient hospitalized in these defined patient care areas were calculated for the studied years (between 2004 and 2013), using data provided by the Database of hospital treatments of the same type based on cost weights for each patient $(14,15)$. Diagnoses were coded with ICD-10 WHO version 1.3. Table 1 presents the list of infectious diseases that we have included in the analysis. Chosen diagnoses were recommended by the Center for Disease Control and Prevention, Atlanta, USA (16).

The University Medical Centre Ljubljana and University Medical Centre Maribor are tertiary and secondary care hospitals. Other ten hospitals (GH Nova Gorica, GH Brežice, GH Novo mesto, GH Celje, GH Izola, GH Jesenice, GH Ptuj, GH Murska Sobota, GH Trbovlje and GH Slovenj Gradec) are secondary type hospitals

The CMI equals the sum of the total cost weights of all inpatients per a defined time period divided by a number of admissions (9). In Slovenia cost weight are regularly recalculated in the databases Groups of applicable cases (in Slovenian language short (skupine primerljivih primerov SPP). 
IBM SPSS Statistics for Windows, Version 21.0 was used for analysis. Weighted linear regression test analysis was performed to determine correlation between antibiotic use and CMI. A p value $\leq$ 0.05 was considered statistically significant.

Table 1: Infection Disease Subgroups Definitions and Corresponding International Classification of Diseases, 9th revision, Clinical Modification (ICD - 9-CM) (16), transcoded to ICD 10th revision

\begin{tabular}{|l|l|}
\hline Diagnosis & Code ICD- 10 \\
\hline Meningitis & A39, G00-G03 \\
\hline Sepsis & A40-A41, O85 \\
\hline Hepatobiliary infections & K83.0, K75.0, K81 \\
\hline Heart infections & I38 \\
\hline Upper respiratory tract infections & A36.0-A36.2, A38, A69.1, J02.0, J32.0- \\
& K12.2, K57.8, K85 \\
\hline Lower respiratory tract infections & A22, A37, J10-J18, J86, J90, J85 \\
\hline Intraabdominal infections & A54.6, K35-K37, K61, K65, K63.0, K12.2, \\
& K57.8, K85 \\
\hline Urinary tract infections & A54.0, N30.0, N34, N39.0, N13.6, N15.1, \\
& $\mathrm{N} 41$ \\
\hline Cellulitis & L02-L08 \\
\hline $\begin{array}{l}\text { Infection and inflammatory } \\
\text { prosthetic devices }\end{array}$ & T82-T89 \\
\hline Postoperative infections & T81.4 \\
\hline Musculoskeletal infections & M86, M90.0- M 90.2 \\
\hline Infection in pregnancy & O0.80, O23, O98, O41.1, O75.3, O85, O91 \\
\hline Pelvic infections & N70, N73.0-N73.2, N72, N76, N75.1, N96.4 \\
\hline
\end{tabular}

\section{Results and Discussions}

\subsection{Antibiotic Consumption}

Antibiotic consumption data are listed in Table 2. From 2004 to 2013 the total antibiotic consumption in all included hospitals was in mean 317.69 DDD / 100 admissions and 58.88 DDD / 100 bed-days. The highest antibiotic consumption with 376.78 DDD / 100 admissions was recorded in GH Nova Gorica and 65.24 DDD / 100 bed-days in GH Celje. In secondary care hospitals antibiotic use ranged from 283.98 to 376.78 DDD / 100 admissions and from 53.47 to 65.24 DDD / 100 bed-days. In University hospitals, Medical Centre Ljubljana and Medical Cetre Maribor, mean antibiotic consumption were 313.10 DDD / 100 admissions and 57.44 DDD / 100 bed-days and 283.98 DDD / 100 admissions and 53.47 DDD / 100 bed-days. From 2004 to 2013 CMI range were from 1.25 to 3.55 . 
Table 2: DDD / 100 admissions and DDD / 100 bed-days and CMI in 12 Slovenian hospitals from 2004 to 2013 (mean)

\begin{tabular}{|l|c|c|c|}
\hline Hospitals & $\begin{array}{c}\text { DDD/100 admissions } \\
\text { mean }\end{array}$ & $\begin{array}{c}\text { DDD/100 } \\
\text { bed-days } \\
\text { mean }\end{array}$ & $\begin{array}{c}\text { CMI } \\
\text { mean }\end{array}$ \\
\hline GH Nova Gorica & 376.78 & 62.37 & 2.06 \\
\hline GH Brežice & 319.85 & 56.80 & 2.11 \\
\hline GH Novo mesto & 311.75 & 59.87 & 2.33 \\
\hline GH Celje & 375.06 & 65.24 & 2.42 \\
\hline GH Izola & 286.83 & 57.45 & 2.05 \\
\hline GH Jesenice & 298.85 & 54.60 & 2.32 \\
\hline UMC Ljubljana & 313.32 & 57.44 & 2.60 \\
\hline GH Ptuj & 325.10 & 64.32 & 2.12 \\
\hline UMC Maribor & 283.98 & 53.47 & 2.54 \\
\hline GH Murska Sobota & 288.20 & 61.52 & 2.07 \\
\hline GH Trbovlje & 309.03 & 54.16 & 2.01 \\
\hline GH Slovenj Gradec & 302.00 & 60.37 & 2.43 \\
\hline
\end{tabular}

Legende: GH - general hospital; UMC-University Medical Centre; DDD - defined daily dose; CMI-case mix index

We calculated DDD / 100 admissions and DDD/100 bed-days for each year from 2004 to 2013. Results are depicted in Table 3. The values were ranged from 296 DDD / 100 admissions in the year 2012 to 336 DDD / 100 admissions in the year 2004 and 56 DDD / 100 bed-days in the years 2012 and 2013 to 61 DDD / 100 bed-days in 2005. The calculated CMI values were ranged from 1.59 in the year 2004 and 2.63 in zhe year 2010.

Table 3: DDD / 100 admissions and DDD / 100 bed-days and CMI for each year from 2004 to 2013

\begin{tabular}{|l|c|c|c|}
\hline Years & DDD/100 admissions & $\begin{array}{c}\text { DDD/100 } \\
\text { bed-days }\end{array}$ & CMI \\
\hline 2004 & 336 & 59 & 1.59 \\
\hline 2005 & 320 & 61 & 1.69 \\
\hline 2006 & 311 & 59 & 1.72 \\
\hline 2007 & 316 & 60 & 1.71 \\
\hline 2008 & 309 & 57 & 2.57 \\
\hline 2009 & 323 & 58 & 2.62 \\
\hline 2010 & 326 & 60 & 2.63 \\
\hline 2011 & 314 & 59 & 2.63 \\
\hline 2012 & 296 & 56 & 2.61 \\
\hline 1013 & 305 & 56 & 2.47 \\
\hline
\end{tabular}

Legende: GH - DDD - defined daily dose; CMI-case mix index 


\subsection{Correlation Between CMI and Antibiotic Use at The Hospitals}

The correlation between antibiotic use and CMI is shown in Figure 1 and Figure 2. Weighted linear regression test analysis was performed to determine correlation between DDD/ 100 admissions and DDD / 100 bed-days and CMI in $10 \mathrm{GHs}$ and two University hospitals from 2004 to 2013. A significant correlation between consumption expressed in DDD / 100 admissions and CMI $\left(\mathrm{R}^{2}\right.$ $=0,018, \mathrm{R}=0.135, \mathrm{p}=0.028)$ and $\mathrm{DDD} / 100$ bed days and $\mathrm{CMI}\left(\mathrm{R}^{2}=0,027, \mathrm{R}=0.163, \mathrm{p}=0.008\right)$ was found.

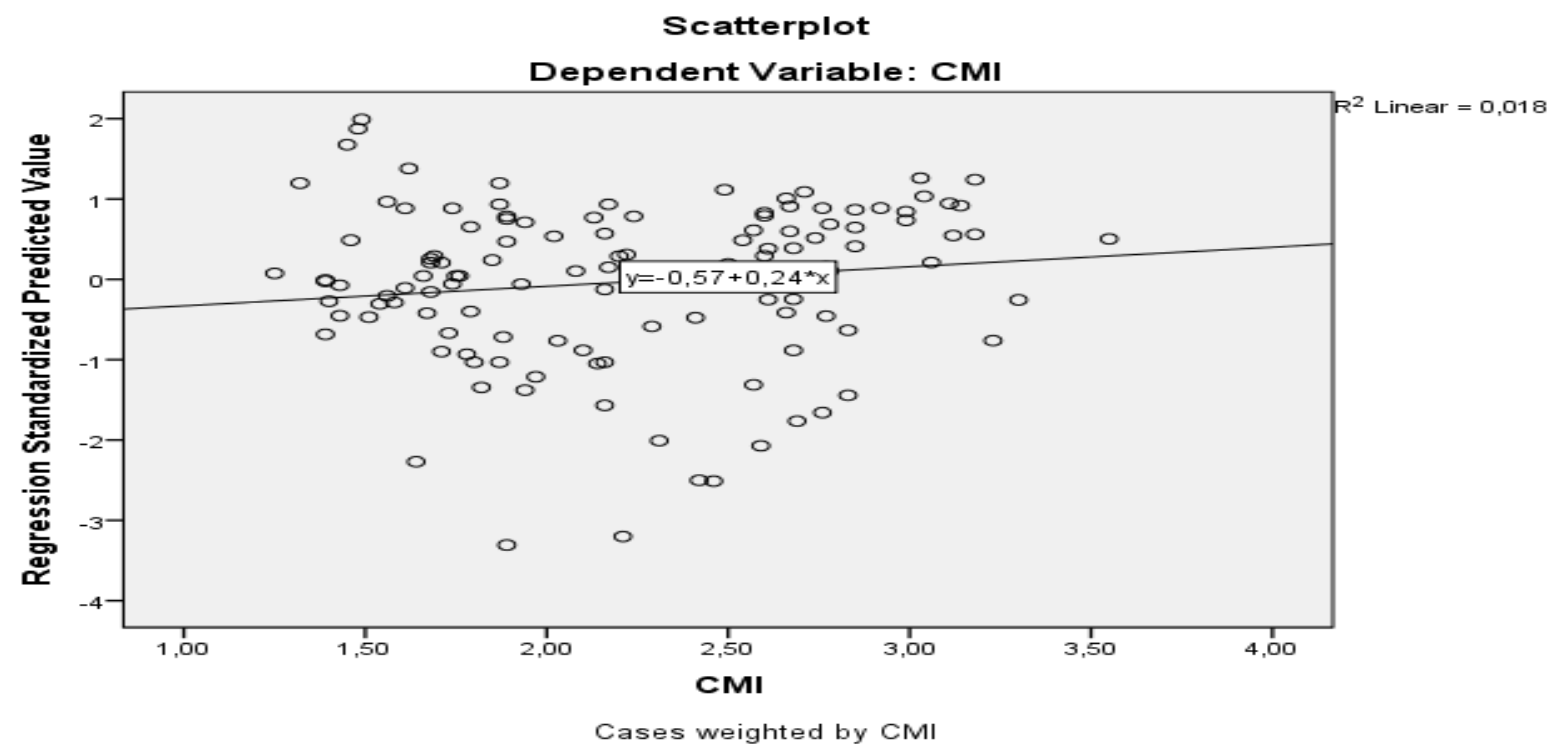

Figure 1: Linear regression between CMI and DDD / 100 admissions in $1 \mathrm{O}$ GHs and 2 University hospitals from 2004 to $2013\left(\mathrm{R}^{2}=0,018, \mathrm{R}=0.135, \mathrm{p}=0.028\right)$

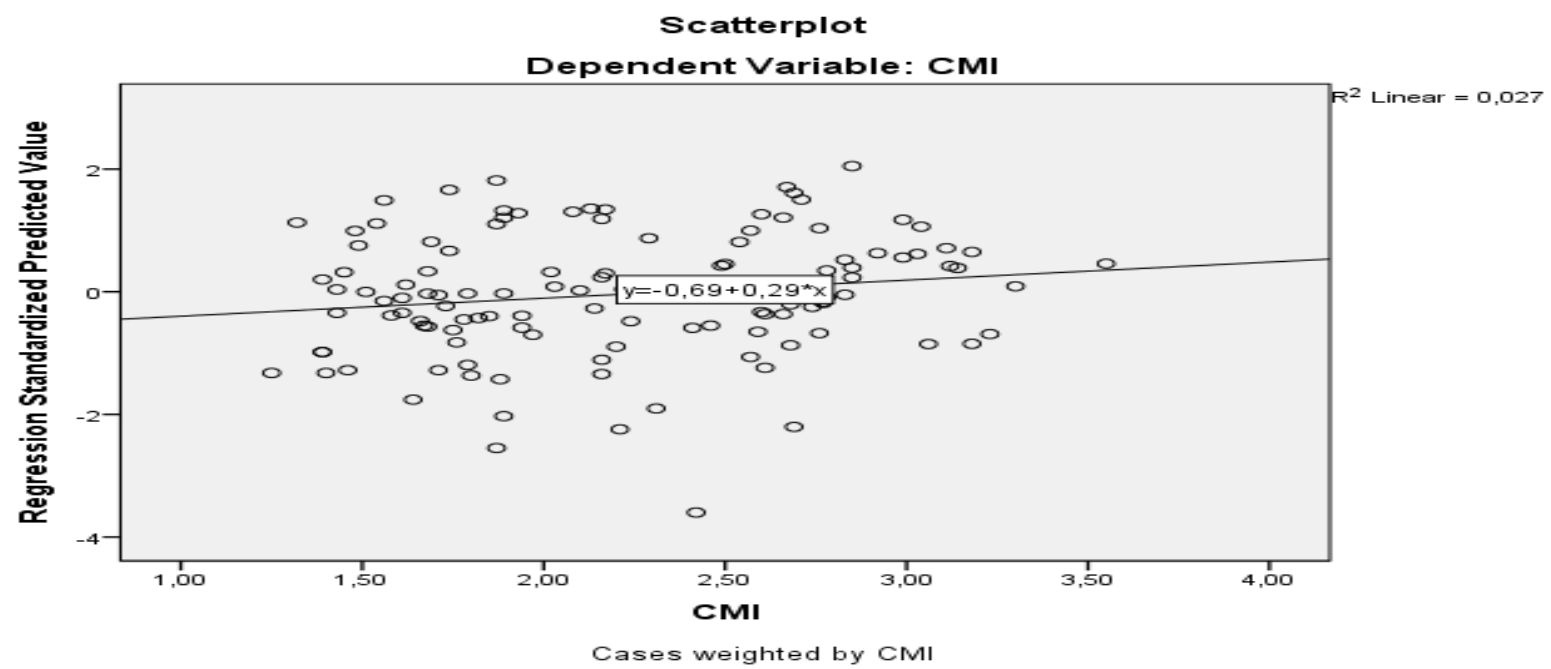

Figure 2: Linear regression between DDD / 100 bed-days and CMI in $10 \mathrm{GHs}$ and 2 University hospitals from 2004 to $2013\left(R^{2}=0,027, R=0.163, p=0.008\right)$ 


\subsection{DDD / 100 admissions and DDD / 100 bed-days and CMI for certain antibiotics most commonly prescribed in Slovenian hospitals from the years 2004 to 2013}

DDD / 100 admissions and DDD / 100 bed days were calculated for certain antibiotics, such as amoxiclav, moxifloxacin, azithromycin, cefuroxim, cefotaxim, antistaphylococcal penicillies, ciprofloxacin, aminoglycoside antibacterials and metronidayole i.v. in mean from 2004 to 2013. Results are shown in Table 4.

Table 4: Mean value of DDD / 100 admissions and CMI calculated from 2004 to 2013 of certain antibiotics

\begin{tabular}{|l|c|c|}
\hline Antibiotics & DDD / 100 admissions (mean) & $\begin{array}{c}\text { DDD / 100 bed days } \\
\text { (mean) }\end{array}$ \\
\hline J01CR02 & 84.754 & 16.802 \\
\hline J01MA14 & 6.808 & 1.276 \\
\hline J01FA10 & 11.696 & 1.855 \\
\hline J01DC02 & 9.893 & 6.692 \\
\hline J01DD01 & 7.664 & 4.442 \\
\hline J01CF & 13.588 & 3.043 \\
\hline J01MA02 & 37.259 & 6.926 \\
\hline J01G & 15.607 & 2.841 \\
\hline J01XD01 & 12.129 & 2.402 \\
\hline
\end{tabular}

Legende: DDD: defined daily dose

J01CR02 - amoxicillin and enzyme inhibitor / amoksicilin in encimski zaviralec

J01MA14 - moxiflocsacin / moksifloksacin

J01FA10 - azithromycin / azitromicin

J01DC02 - cefuroxime / cefuroksim

JO1DD01 - cefotaxime / cefotaksim

J01CF - antistaphylococcal penicillies / protistafilokokni penicilini

J01MA02 - ciprofloxacin / ciprofloksacin

J01G - / aminoglikozidi

J01XD01 - metronidayole i.v. / metronidazol i.v.

\subsection{DDD / 100 Admissions and DDD / 100 Bed-Days and CMI For Certain Antibiotics Most Commonly Prescribed in Slovenian Hospitals for Each Year from The Years 2004 To 2013}

DDD / 100 admissions and DDD / 100 bed-days were calculated for certain antibiotics, such as amoxiclav, moxifloxacin, azithromycin, cefuroxim, cefotaxim, antistaphylococcal penicillies, ciprofloxacin, aminoglycoside antibacterials and metronidayole i.v. for each year from 2004 to 2013. Results are shown in Table 5 and 6. 
Table 5: DDD / 100 admissions calculated for each year from 2004 to 2013 for certain antibiotics

\begin{tabular}{|l|c|c|c|c|c|c|c|c|c|}
\hline Years & J01CR02 & J01MA14 & J01FA10 & J01DC02 & JO1DD01 & J01CF & J01MA02 & J01G & J01XD01 \\
\hline $\mathbf{2 0 0 4}$ & 82,09 & 6,64 & 13,08 & 17,19 & 11,68 & 18,68 & 37,52 & 15,85 & 11,50 \\
\hline $\mathbf{2 0 0 5}$ & 85,19 & 6,77 & 13,51 & 20,69 & 10,55 & 20,98 & 38,93 & 14,61 & 12,05 \\
\hline $\mathbf{2 0 0 6}$ & 86,98 & 7,46 & 14,72 & 17,83 & 5,71 & 22,10 & 39,59 & 14,54 & 13,39 \\
\hline $\mathbf{2 0 0 7}$ & 83,38 & 6,99 & 13,64 & 15,63 & 4,14 & 23,19 & 38,08 & 13,60 & 13,43 \\
\hline $\mathbf{2 0 0 8}$ & 82,68 & 6,75 & 12,45 & 13,70 & 3,76 & 24,12 & 36,59 & 12,96 & 12,61 \\
\hline $\mathbf{2 0 0 9}$ & 84,69 & 6,31 & 11,93 & 13,89 & 3,12 & 23,68 & 36,06 & 12,01 & 12,17 \\
\hline $\mathbf{2 0 1 0}$ & 86,13 & 5,38 & 9,08 & MV & 8,78 &, 73 & 38,59 & 18,71 & 12,73 \\
\hline $\mathbf{2 0 1 1}$ & 82,90 & 6,50 & 9,38 & MV & 9,66 &, 80 & 36,47 & 18,10 & 11,80 \\
\hline $\mathbf{2 0 1 2}$ & 84,81 & 7,52 & 8,42 & MV & 9,76 &, 81 & 35,53 & 18,28 & 11,33 \\
\hline $\mathbf{2 0 1 3}$ & 88,69 & 7,76 & 10,75 & MV & 9,48 &, 79 & 35,23 & 17,41 & 10,28 \\
\hline
\end{tabular}

\section{Legende:}

J01CR02 - amoxicillin and enzyme inhibitor / amoksicilin in encimski zaviralec

J01MA14 - moxiflocsacin / moksifloksacin

J01FA10 - azithromycin / azitromicin

J01DC02 - cefuroxime / cefuroksim

JO1DD01 - cefotaxime / cefotaksim

J01CF - antistaphylococcal penicillies / protistafilokokni penicilini

J01MA02 - ciprofloxacin / ciprofloksacin

J01G - aminoglycoside antibacterials / aminoglikozidi

J01XD01 - metronidayole i.v. / metronidazol i.v.

MV / missing value

Table 6: DDD / 100 bed-days calculated for each year from 2004 to 2013 of certain antibiotics

\begin{tabular}{|l|c|c|c|c|c|c|c|c|c|}
\hline Years & J01CR02 & J01MA14 & J01FA10 & J01DC02 & JO1DD01 & J01CF & J01MA02 & J01G & J01XD01 \\
\hline $\mathbf{2 0 0 4}$ & 13,63 & 1,12 & 2,17 & 2,86 & 1,94 & 3,10 & 6,23 & 2,63 & 1,91 \\
\hline $\mathbf{2 0 0 5}$ & 14,47 & 1,27 & 2,29 & 3,51 & 1,79 & 3,56 & 6,61 & 2,48 & 2,05 \\
\hline $\mathbf{2 0 0 6}$ & 15,13 & 1,22 & 2,56 & 3,10 &, 99 & 3,85 & 6,89 & 2,53 & 2,33 \\
\hline $\mathbf{2 0 0 7}$ & 15,55 & 1,26 & 2,54 & 2,92 &, 77 & 4,33 & 7,10 & 2,54 & 2,50 \\
\hline $\mathbf{2 0 0 8}$ & 15,38 & 1,17 & 2,32 & 2,55 &, 70 & 4,49 & 6,81 & 2,41 & 2,35 \\
\hline $\mathbf{2 0 0 9}$ & 15,20 & 1,07 & 2,14 & 2,49 &, 56 & 4,25 & 6,47 & 2,15 & 2,18 \\
\hline $\mathbf{2 0 1 0}$ & 20,39 &, 84 & 2,78 & 13,49 & 8,78 & 1,56 & 7,42 & 3,34 & 2,80 \\
\hline $\mathbf{2 0 1 1}$ & 17,56 & 1,38 &, 60 & 13,77 & 9,65 & 1,78 & 7,37 & 3,43 & 2,69 \\
\hline $\mathbf{2 0 1 2}$ & 20,01 & 1,75 &, 49 & 11,66 & 9,76 & 1,77 & 7,24 & 3,49 & 2,68 \\
\hline $\mathbf{2 0 1 3}$ & 20,70 & 1,68 &, 66 & 10,57 & 9,48 & 1,74 & 7,12 & 3,41 & 2,53 \\
\hline
\end{tabular}

\section{Legende:}

J01CR02 - amoxicillin and enzyme inhibitor / amoksicilin in encimski zaviralec

J01MA14 - moxiflocsacin / moksifloksacin

J01FA10 - azithromycin / azitromicin

J01DC02 - cefuroxime / cefuroksim

JO1DD01 - cefotaxime / cefotaksim

J01CF - antistaphylococcal penicillies / protistafilokokni penicilini 
J01MA02 - ciprofloxacin / ciprofloksacin

J01G - aminoglycoside antibacterials / aminoglikozidi

J01XD01 - metronidayole i.v. / metronidazol i.v.

Our results shown that from 2004 to 2013 the total antibiotic consumption in all included hospitals were in average 315.63 DDD / 100 admissions and 59.02 DDD / 100 bed days. Kuster et all. described overall antibiotic use in University hospitals in Zurich where it was 491.62 DDD/100 admissions and 68.04 DDD/100 bed-days. The corresponding numbers for the two secondary care hospitals were 39.46 and 50.56 DDD / 100 bed-days and 268.59 and 383.77 DDD / 100 admissions (9). Kern et all. found the overall antibiotic use density in German acute care hospitals 43.5 recommended daily dose (RDD) per 100 patient days (occupied bed days) (median) with the interquartile range of 35-48 RDD / 100 - corresponding to a median of 64.4 DDD / 100 (interquartile range, 53 - 73 DDD / 100) (17). National monitoring of hospital consumption of antimicrobial drugs are indicators of quality, expressed in DDD / 100 admissions and DDD / 100 bed-days (18). In 2007 the national hospital consumption of antibiotics for systemic use was in Denmark DDD / 100 admissions, 288.7in Sweden DDD/ 100 admissions, 278.8 and in the Netherlands DDD/ 100 admissions, 355 (19). Total consumption of antibiotics in Slovenia in GHs in comparison with other countries with more rational prescribing of antibiotics is higher than in Denmark and Sweden and a surprisingly lower than in the Netherlands in 2007 (20). In second Slovenian national healthcare-associated infections (HAIs) prevalence survey (SNHPS) was conducted in acute-care hospitals in 2011. The objective was to assess the sensitivity and specificity of the method used for the ascertainment of six types of HAIs (bloodstream infections, catheter-associated infections, lower respiratory tract infections, and urinary tract infections) in the University Medical Centre Ljubljana. The overall sensitivity of SNPHS collection method for ascertaining HAIs overall was high and the specificity was very high (21). In the second Slovenian national HAIs prevalence survey, conducted within European point prevalence survey of HAIs and antimicrobial use in acute care hospitals, they estimated the prevalence of all types of HAIs and identified risk factors. They found that the prevalence of HAIs in Slovenian acute care hospitals in 2011 was substantial, especially in ICUs. HAIs prevention and control is an important public health priority (22).

Data on the correlation of cost indicators and antibiotic use are limited in the current literature. Our study is the first such survey in Slovenia. We found a statistical significant correlation between antibiotic use and CMI when analysing data of Slovenian hospitals from 2004 to 2013. Correlation was strong significant $(\mathrm{p}=0.028$ and $\mathrm{p}=0.008$, respectively). We demonstrate differences between CMI and antibiotic use in 12 studied hospitals and results are comparable with the studies. Kuster at all. presented the first study to evaluate such a correlation between CMI and antibiotic use within a single institution and across various acute care hospitals. Antibiotic use varied substantially between different departments of the University hospital and between primary and secondary care hospitals. Kunster et all. recommended antibiotic use within and across hospitals, adjustment for CMI as a useful tool in order to take into account the differences in hospital category and patients' morbidities (9). Polk et all. shows of 1791180 discharged adults, $63.7 \%$ received antibacterial drugs. Mean \pm SD hospital-wide use was $839 \pm 106$ days of therapy's (DOTs) (range, 594-1109) and $536 \pm 53.0$ length of therapy (LOT) (range, 427-684) per 1000 patient-days. Differences between expected and observed use reflect usage patterns that were benchmarked and are targets for evaluation and intervention (23). In 2008, the Slovenian hospitals most commonly 
prescribed penicillins (39.8\%), cephalosporins (22.8\%), quinolones (14.6\%) macrolides to lincosamides $(9.2 \%)$ and other antibacterial agents $(5.3 \%)(19,20)$. These groups are often prescribed in other European countries (24). In our study we calculated DDD / 100 admissions and 100 bed-days for amoxiclav, moxifloxacin, azithromycin, cefuroxim, cefotaxim, antistaphylococcal penicillies, ciprofloxacin, aminoglycoside antibacterials and metronidayole i.v. in mean from 2004 to 2013. Results shown high consumption of amoxiclav, azithromycin, cefuroxim, cefotaxim, antistaphylococcal penicillies, ciprofloxacin, aminoglycoside antibacterials and metronidayole i.v. and low consuption of moxifloxacin. On internistic intesive care units (ICU) in Slovenia increased use of penicillins in combination with beta-lactamase inhibitors, cephalosporins 1st and 4th generation, and carbapenems. In surgical ICU it similar to Internistic increased use of penicillins in combination with beta-lactamase inhibitors, the 4th generation cephalosporins, carbapenems (25). In recent ESAC Annual Report published in 2014, in the hospital sector, consumption of antibacterials for systemic use data varied from 1.0 DDD per 1 000 inhabitants and per day in the Netherlands, to 2.8 in Finland. The population-weighted EU/EEA mean consumption was 2.0 DDD per 1000 inhabitants and per day and no significant trends in the mean consumption are apparent for the last five years. The most frequently used subgroup in the hospital sector was penicillins, followed by other beta-lactam antibacterials including cephalosporins and quinolones (26).

\section{Conclusions and Recommendations}

Thus, detailed analysis of correlations between DDD of antibiotics and CMI may constitutes a proper use of antibiotics. Conclusion. The CMI maybe a valuable tool to facilitate the interpretation of quantitative hospital antibiotics data.

\section{References}

[1] Ansari F, Ernetll M, Goossen H, Davey P. The European Surveillance of Aantimicrobial Consumption (ESAC) Point-Prevalence Survey of Antibacterial Use In 20 European Hospitals In 2006. Clinical Infectious Diseases. Vol. 49, No. 10, November 2009, 1496-504.

[2] Vander Stichele RH, Elseviers MM, Ferech M, et al. Hospital Consumption Of Antibiotics In 15 European Countries: Results Of The ESAC Retrospective Data Collection 1997-2002. Journal of Antimicrobial Chemotherapy. Vol. 58, No. 1, July 2006, 159-67.

[3] Dumartin C, L' Heriteau F, Pefau M, Bertrand X, Jarno P, et al. Antibiotic Use In 530 French Hospitals: Results from A Surveillance Network At Hospital And Ward Levels In 2007. Journal of Antimicrobial Chemotherapy. Vol. 65, No. 9, September 2010.

[4] Pokrajac T. Ekonomsko Breme Pogostih Nalezljivih Bolezni V Sloveniji. Diplomsko delo. Ljubljana: Medicinska fakulteta; 2014.

[5] Pokrajac T, Truden-Dobrin P, Beovič B, Čižman M. Pogostnost Ambulantnih In Bolnišničnih Obravnav Ookužb V Sloveniji. V: Beović B, Strle F, Čižman M, eds. Infektološki simpozij. Ljubljana: Sekcija za kemoterapijo; 2008.

[6] ECDC. Annual Epidemiological Report Reporting On 2011 Surveillance Data And 2012 Epidemic Intelligence Data 2013. Stockholm: ECDC; 2013.

[7] Kritsotakis E, Gikas A. Surveillance of Antibiotic Use In Hospitals: Methods, Trends And Targets. Clinical of Microbiology Infection. Vol. 12, No.8, September 2006, 12: 701-4.

[8] Kuster SP, Ruef C, Bollinger AK, et al. Correlation Between Case Mix Index And Antibiotic Use In Hospitals. Journal Of Antimicrobial Chemotherapy. Vol. 62, No. 4, October 2008; 837-42 
[9] Willemsen I, Groenhuijzen A, Bogaers D, et al. Appropirateness Of Antimicrobial Therapy Measured By Repeated Prevalence Surveys. Antimicrobial Agents Chemotherapy. Vol. 51, No. 3, March 2007, 864-867.

[10] Čižman M, Beovič B. Kako Predpisujemo Protimikrobno Zdravila V Bolnišnicah? Ljubljana: Sekcija za kemoterapijo, 2007.

[11] WHO Collaborating Centre For Drug Statistic Methodology. ATC Index with DDDs.

[12] Available January 10, 2016 from: http://www.whocc.no/.

[13] Zdravstveni Statistični Letopis 2013. Nacionalni Nnštitut Za Javno Zdravje RS, Ljubljana 2013.

[14] Zbirka Bolnišničnih Obravnav (Združene Eepizode Hospitalizacij Po Diagnozah) 2004 - 2013). Nacionalni Inštitut Za Javno Zdravje RS, Ljubljana 2005 - 2014.

[15] Zbirka Bolnišničnih Obravnav Istega Tipa (SPP) Zaradi Bolezni 2004 - 2013. Nacionalni Inštitut Za Javno Zdravje RS, Ljubljana 2005 - 2014.

[16] Čižman M. Poraba Antibiotikov V Slovenskih Bolnišnicah V Letu 2011. ISIS. Vol. 11, 2012, 646.

[17] Kwint HM, Van Der Linden PD, Roukens MM, et al. Intensification of Antibiotic Use Within Acute Care Hospitals In The Netherldands. Journal of Antimicrobial Chemotherapy. Vol 67, No. 9, May 2012, 2283-8.

[18] Mednarodna Klasifikacija Bolezni In Sorodnih Zdravstvenih Problemov Za Statistične Namene, Deseta Revizija (MKB-10). Ljubljana: Inštitut Za Varovanje Zdravja Republike Slovenije, 1995.

[19] Simonsen L, Conn LA, Pinner RW, et al. Trends in Infectious Disease Hospitalization In The United States, 1980 - 1994. Archives Of Internal Medicine. Vol. 158, No. 17, September 1998, 1923-8.

[20] Kern Wv, Fellhauter M, Hug M, et al. Recent Antibiotic Use In German Acute Care Hospital From Benchmarking To Improve Prescribing And Qulity Care. Deutsche Medizinische Wochenschrift. Vol. 140, No. 23, November 2015, 237-46.

[21] Čižman M. Slovenian Consumption Study Group. Nationwide Hospital aantibiotic Consumption in Slovenia. Journal of Antimicrobial Chemotherapy. Vol. 66, No. 9, June 2011, 2189-91.

[22] Serdt M. Sensitivity and Specificity of The Method Used for Ascertainment Of HealthcareAssociated Infections In The Second Slovenian National Prevalence Survey. Slovenian Jornal of Public Health. Vol. 55, No. 4, July 2016, 248-255.

[23] Klavs I. The Prevalence of And Risk Factors for Healthcare Associated Infections In Slovenia. Slovenian Journal of Public health. Vol. 55, No. 4, July 2016, 239-47.

[24] Polk RE, Hohmann SF, Medvdev S, Ibrahim O. Benchmarking Risk-Adjusted Adult Antibacterial Drug Use in 70 US Academic Medical Center Hospitals. Clinical Infectious Diseases. Vol. 53, No. 11, December 2011, 1100-10.

[25] Berrington A. Antimicrobial Prescribing In Hospitals: Be Careful What You Measure. Journal Of Antimicrobial Chemother. Vol. 5, No. 1, January 2010, 163-8.

[26] Jereb M. Antibiotično Zdravljenje Na Oddelkih Zza Intenzivno Zdravljenje V Sloveniji. Zbornik Predavanj. 20. Simpozij Intenzivne Medicine In 17. Seminar Intenzivne Medicine Za Medicinske Sestre In Zdravstvene Tehnike. Zbornik Predavanj: Bled; 2011.

[27] EDCD. Surveillance of Antimicrobial Consumption In Europe 2012. Stockholm: ECDC; 2014

*Corresponding author.

E-mail address: ghulamhonaryar@ gmail.com 